\title{
DEVELOPMENT OF THE LEGAL REGULATION OF THE COOPERATIVE AS A FORM OF BUSINESS IN AGRICULTURE IN SLOVAKIA
}

\author{
Zuzana Ilková ${ }^{1}$ \\ Zuzana Lazíková ${ }^{2}$ \\ Anna Bandlerová ${ }^{3}$ \\ Jarmila Lazíková ${ }^{4}$
}

DOI: https://doi.org/10.31410/ERAZ.2019.315

\begin{abstract}
The paper analyzes the development of the legislation of cooperative law since the late 1940s. It points out the positives, but also the negatives in the development of agricultural cooperative in Slovakia. The number of cooperatives, as well as the area of their farmed land decreased significantly after 1989 and the number of legal entities operating on the land has expanded. In spite of this, however, according to the collected data, it can be stated that in 2018, cooperatives managed 34, 25\% of agricultural land in Slovakia. Based on the available statistical data on the development of the structure of agricultural cooperatives and on the basis of legal analysis of the legislation, the authors wish to emphasize the merits of the cooperative form of business as well as the advantages of the cooperatives as a separate form of business under current market conditions. The cooperative, as a separated form of business, is still advantageous for all areas of business including the agricultural business. The advantage of a cooperative form of business is highlighted by its flexibility, relatively simple and more liberal than other legal form of business.
\end{abstract}

Keywords: cooperative, legal form, legal relations, development of legislation, agriculture.

\section{INTRODUCTION}

- $m$ mhasizing the historical development and importance of agriculture for the national econComy, it can be argued that social relations in the area of regulating the forms of farming on land have always been in the focus of the whole society. The social interest aimed at regulating the legal relations of entities farming on agricultural land has been reflected in many legislative adjustments in recent decades. However, it should be stressed that the development of formal sources of law, as well as the subject of their regulation, reflects and materializes the social conditions in which the relevant legislation is created.

\section{MATERIAL AND METHODS}

Legal form of the cooperative underwent complicated development. According to the applicable legislation, the cooperative is a business entity traditionally active mainly in the field of agricultural business.

The aim of the paper is to point out, on the basis of a legal analysis, the development of the law of cooperative law from the end of the 1940s and on the basis of the comparison and logical

\footnotetext{
Department of Law, Slovak University of Agriculture in Nitra, Tr. A. Hlinku 2, 94976 Nitra, Slovakia Department of Law, Slovak University of Agriculture in Nitra, Tr. A. Hlinku 2, 94976 Nitra, Slovakia Department of Law, Slovak University of Agriculture in Nitra, Tr. A. Hlinku 2, 94976 Nitra, Slovakia Department of Law, Slovak University of Agriculture in Nitra, Tr. A. Hlinku 2, 94976 Nitra, Slovakia
} 
method of cognition, the positives and negatives in the development of agricultural cooperatives and the advantages of current legislation. The paper uses logical methods, formal legal methods, and sociological methods, especially the methods of examining various documents that preceded or accompanied the creation of normative legal acts.

\section{RESULTS AND DISCISSION}

\subsection{Historical development of cooperatives in Slovakia}

In 2019, we commemorate the 174th anniversary of the beginning of the cooperative movement in Slovakia with the foundation of the Association Gazdovsky spolok in the village Sobotište. It was the first credit cooperative in the world. The guiding principles of this Association were voluntary entry, self-help, reciprocity and self-government. According to its model, other cooperatives and associations were established in almost all of Slovakia.

One of the first legal regulations of cooperatives in our territory can be considered the Hungarian Commercial Code, legal article XXXVII/1875, supplemented by the Cooperative Law, the legal article XXIII/1898 on economic and trade credit cooperatives (Š́bertová, 2004). The general regulation of cooperatives was enshrined together with trading companies in the first part of the Hungarian Commercial Code. A cooperative has been set up as a form of trading company, consisting of an indefinite number of members, created for the purpose of joint business management or other economic purpose. The Hungarian Commercial Code remained valid in Slovakia even after the establishment of the Czechoslovak Republic.

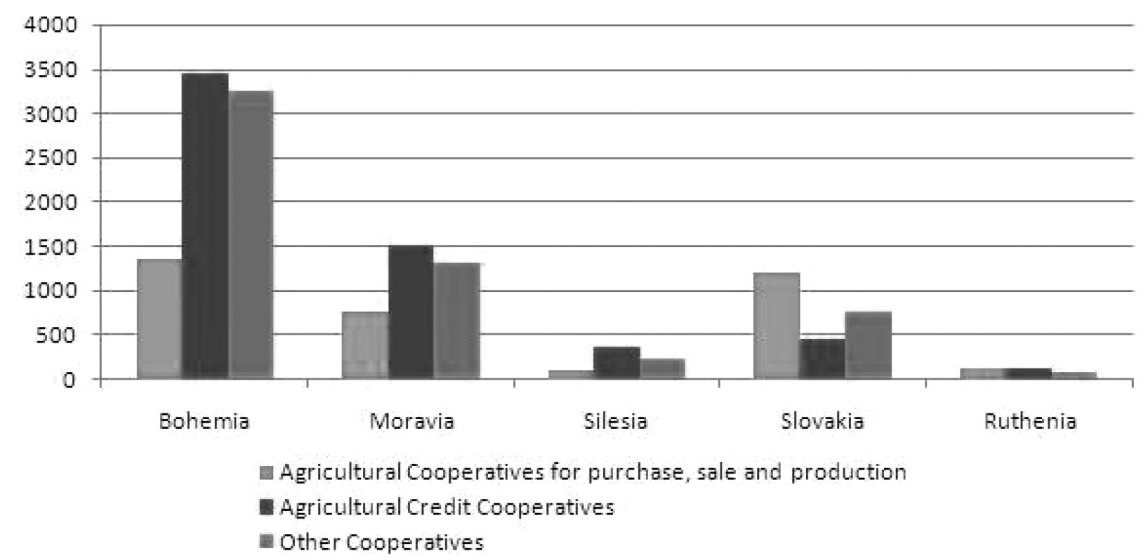

Figure 1: Overview of cooperatives in Czechoslovak republic in early 1924 Source: own processing at the Department of Law according to Demo et al.: History of Agriculture in Slovakia (Table 12.1 p. 444)

Despite the unification efforts (Gábriš, 2012) in the period of the first Czechoslovak Republic, the commercial law failed to unify. During the entire existence of the first Czechoslovak Republic, the second Czechoslovak Republic and the Slovak State, the former Austrian Commercial Code of 1863 still applied in the Czech lands and the Commercial Code of 1875 still applied in Slovakia. This means that the legislation of the cooperative was also split into two commercial codes. The legal situation lasted until 1950, when the Civil Code no. 141/1950 Coll. has been adopted, which repealed both commercial codes, except for the provisions governing cooperative law. Figure 1 is an overview of the number of cooperatives in the mid-1920s throughout the Czechoslovak Republic. According to Demo et al. (2001) from most of the total number of 
14,924 cooperatives, 3,479 were agricultural, purchasing, selling and production cooperatives and 5,852 were agricultural credit cooperatives.

The constitutional development after „February 1948” was influenced by the political conditions of its origin and the changes that occurred in all areas of the state's social life. The Constitution of the Czechoslovak Republic, established a people-democratic establishment where the people are the source of all power in the state.

The empowering provisions laid down in the Constitution of the Czechoslovak Republic concerning the ownership of agricultural land were elaborated in Act no. 69/1949 on Common Agricultural Cooperatives (hereinafter referred to as the CAC Act or the Act). The CAC Act constituted and established a normative regulation of the rebuilding of agriculture by the association of individual farmers. It was a simple framework regulation that within 14 paragraphs enshrined and brought substantial changes in the life of farmers and substantial changes in land management. The aim of the legal regulation was to eliminate the existing fragmentation of cooperative activities in agriculture, to unite various agricultural cooperatives by voluntary establishment of common agricultural cooperatives.

The first stage of searching for a suitable type of cooperative and collective founding of common cooperatives represented by Act no. 69/1949 Coll. ends with the adoption of Act no. 49/1959 Coll. on CAC (with effect from 1 October 1959), by which begins the second stage of development of agricultural cooperatives, namely the stage of consolidation and development of common agricultural cooperatives ( $\$ 1$ of the Act). By its modification and content, the second CAC Act is the holder of all socio-economic conditions for the development of Czechoslovak society at that time. The members of the cooperative were obliged to associate the lands, including forest lands, for the cooperative management in the scope and under the conditions determined by the Statutes, while the ownership of the associated land remains intact and the cooperative acquires the right to cooperative use. This legal regulation gave preference to the right of use before the right of the owner. Although the ownership of the land belonging to the cooperative was retained to the members, they lost one significant ownership right, namely the right to dispose with the land, because the Act stipulated the restriction of the owner of the associated land to be disposed of or burdened.

The second Act on Common Agricultural Cooperatives (Act no. 49/1959 Coll.) significantly contributed to the development of the cooperative movement in agriculture, to the consolidation of the cooperative form of farming on agricultural land and to the development of legal relations in cooperatives. The legal regulation reflects the then existing political, social and production relations, which were also reflected in the newly adopted Constitution of the Czechoslovak Socialist Republic (Constitutional Act no. 100/1960 Coll.). Figure 2 is an overview of the common agricultural cooperatives over the ten-year period 1950 - 1960. In 1960, the number of cooperatives increased to 2,683 , which were farming on $65.8 \%$ of agricultural land.

The CAC Act was effective for 15 years until the adoption of the new statutory regulation by Act no. 122/1975 Coll. on Agricultural Cooperatives, by which starting a new stage of development of agricultural cooperatives, namely the stage of development of agri-food complex and concentration of production based on specialization and merging of cooperatives. The legal regulation emphasized the importance of the socialist agricultural cooperative and its state management and the nature, tasks, subject of activity and management of the cooperative have been established. 


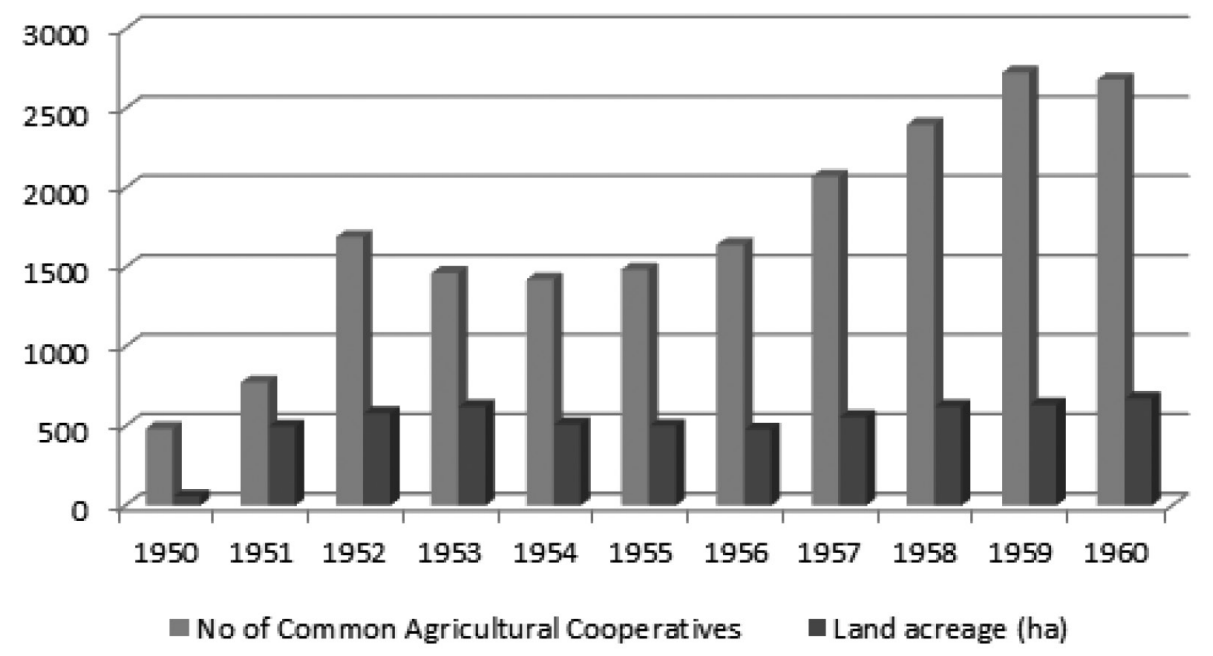

Figure 2: Establishment of common agricultural cooperatives (CAC) of the type III and IV in Slovakia until 1960

Source: own processing at the Department of Law according to Demo et al.:

History of Agriculture in Slovakia (Table 12.6 s.462)

The effectiveness of the Act on Agricultural Cooperatives lasted until July 1 1988, when the new Act no.90/1988 Coll. on Agricultural Cooperatives. The new Act on Agricultural Cooperatives does not bring major changes compared to the previous regulation. It is more transparent in the regulation of the legal status of the members of the cooperative, because in one part it regulates both the member and labour relations of the members, the cooperative discipline and the disciplinary measure. In addition to this Act, the labour relations of the members were governed by an amendment in their own statutes and, supportively, by the Labour Code.

Same as the previous regulation, the Act is based on the regulation of the right of cooperative use of associated land, which provides it for free and in unlimited time and entitles the cooperative to use land for fulfilling all its tasks. For the first time, the Act provides for the pursuit of foreign-economic activities and the establishment of a foreign exchange fund when regulating the cooperative's subject of activity.

On 15 May 1990, the third Act on Agricultural Cooperatives (Act no. 162/1990 Coll.) were adopted and entered into force. The provisions of the Act reflect the social, economic and constitutional changes of the ,,velvet revolution”. In the first and the second part of the legal regulation, in addition to the conceptual definition of the „cooperative", the formation of the cooperative and the requirements of the statutes were modified. The statutes stipulate among the mandatory requirements for the first time a provision on the amount and manner of determining the amount of a member's share, or basic membership fee or other ownership interest, the types and methods of their creation, use, evaluation or amortization, the method of subscription and their arrangement at cessation of membership. In addition to this regulation, the Act documents the effort to transform existing cooperatives into share cooperatives.

Based on the requirements of the given period, the Act contains a regulation of an agreement negotiated between the cooperative and members or other citizens on joint production. The Act allows the establishment of self-help cooperatives of farmers, which can be set up by citizens carrying out agricultural activities. The third Act on Agricultural Cooperatives was repealed by the Commercial Code, which entered into force on 1 January 1992. 
The Department of Law of the Slovak University of Agriculture in Nitra in its research activities, in cooperation with practice, consulting and advisory activities, has gained much knowledge on past development from former self-employed farmers, members of cooperatives, cooperatives' managers, students and their family members and other citizens for whom the development of agriculture was not indifferent. Opinions and findings can be divided into two groups: (1) the group whose opinions condemning the development and its negative impact on private farmers and (2) the second group of views on the development of the cooperative as well as on the development of the relevant co-operative legislation, which understands this process positively. Critically assessed is the violation of the voluntary principle when entering the cooperative in the first stage of the cooperatives' establishment, either directly, e.g. by criminal prosecution of many resistant farmers, their displacement, various forms of intimidation of family members, or indirectly, by burdening private farmers with high mandatory supplies of agricultural products, socalled contingents in order to provide enough food for the post-war period, which actually forced the farmers to enter the CAC. Negatively assessed are the right of association of agricultural land and the creation of a new original right of cooperative land use, which prevailed over the land ownership right of individual cooperative members. Part of the right of use of the land was free of charge. According to the opinions, the cooperatives, in particular in the late 1950s and early 1960s, were economically stabilized and had sufficient funds to pay the rent for land use. From the 1970s, the process of merging agricultural cooperatives violating the principle that one agricultural cooperative should be established in each municipality is critically perceived. Although the large complexes have been created by merging cooperatives, where large-scale technology has been used more effectively, at the same time, the immediate relationship, the daily care of members for „their municipal cooperative”, has disappeared and the merged cooperatives themselves have invested more in the development of the municipality in which they had they seat.

The second group of views on the development of the co-operative as well as on the development of the relevant co-operative legislation understands this process positively. According to these opinions, cooperatives have made a significant contribution to the development of agriculture and thus to rural development. Cooperatives have played a positive role in ensuring self-sufficiency in the production of plant and animal products, and the share of agricultural cooperatives in the development of rural employment is also important.

\subsection{Development of agricultural cooperatives after 1990}

The social and economic changes after 1989 also meant serious property and organizational impacts for cooperatives.

The basic regulation governing the legal status of cooperatives was the Commercial Code adopted in 1991 (Act no. 513/1991 Coll.), which established a common legal form of a cooperative regardless of the subject of activity. In terms of legislation, a cooperative is a business entity, a community of open number of persons, established for the purpose of carrying out business or providing for its members' economic, social or other needs. It differs from trading companies by the special regulation of internal relationships between the cooperative and members and between individual members. In its provision $\S 765$, the Commercial Code imposed on cooperatives that were established prior to its entry into force (1 January 1992) to be converted into companies or cooperatives governed by the Commercial Code by a procedure governed by a separate act. This act was Act no. 42/1992 Coll. on the regulation of property relations and settlement of property claims in cooperatives. 
In addition, other legislation was gradually approved to implement structural changes in agriculture, through which the transition from a centrally planned economy to a market economy should be carried out. These changes were enshrined in the Constitution of the Slovak Republic.

Land-based business activities have been significantly affected by property restitution: Act no. 403/1990 Coll. on mitigation of some property injustice; Act no. 87/1991 Coll. on Extrajudicial Rehabilitation; Act no. 229/1991 Coll. on regulation of ownership relations to land and other agricultural property as amended (the First Restitution Act); Act no. 503/2003 Coll. on restitution of ownership to land (the Second Restitution Act). The privatization of state-owned enterprises was regulated by Act no. 92/1991 Coll. on conditions of transfer of state property to other persons (Act on Large-Scale Privatization).

Even before the process of cooperative transformation, the cooperative regulation mentioned in Act no. 427/1990 Coll. on the transfer of state ownership of certain entities to other legal entities and physical persons (Small Privatization Act), which blocked cooperatives from obtaining shares in privatized food production and commercial establishments. This avoids the connection between primary production represented by agricultural cooperatives with processors and trade.

The process of transformation of agricultural cooperatives itself was carried out on the basis of Act no. 42/1992 Coll. on the regulation of property relations and settlement of property claims in cooperatives (the so-called Transformation Act). The most important amendments were Act no. 264/1995 Coll. and Act no. 3/2005 Coll. The Transformation Act established firstly, method of regulation of the property relations and settling property claims in cooperatives by designating eligible persons, evaluating cooperative assets, quantifying net worth, determining the ownership shares of beneficiaries, developing and adopting a transformation project; secondly, method of adapting the internal legal conditions of the cooperative to the Commercial Code and thirdly, eligible persons could also opt for a different form of business than the cooperative; therefore the Act also stipulated the method of converting cooperatives into other business forms under the Commercial Code. As a result of the transformation of the cooperative, a transformation project was approved, which included a decision on the further existence of the cooperative or its transformation into a business company.

According to opinion of Lazíková and Bandlerová (2005), there are two groups of cooperatives that exist in Slovakia since the 1990s. There are (1) cooperatives that have not undergone a transformation process (cooperatives established after 1992), which already have a better starting point for doing business by not having started to act as indebted entities; and (2) cooperatives that have undergone a transformation process (cooperatives established before 1992). A special feature of transformed cooperatives is the fact that property rights in them have persons who are not their members. This situation is disadvantageous for both parties. On the one hand, there are eligible persons who are not members of the cooperative but have property rights in it, but cannot interfere with the management of the cooperative as the members of the cooperative. On the other hand, there are the cooperative members, who are not the exclusive owners of the cooperative's assets.

Over the last almost twenty years, agricultural cooperatives have gone through complex changes, both in terms of normative regulations and structural changes in the agricultural sector. The following Figure 3 shows the development trend of the number of agricultural cooperatives in Slovakia, as well as the development trend of the average area of agricultural land that they farmed in $1970-2010$. 


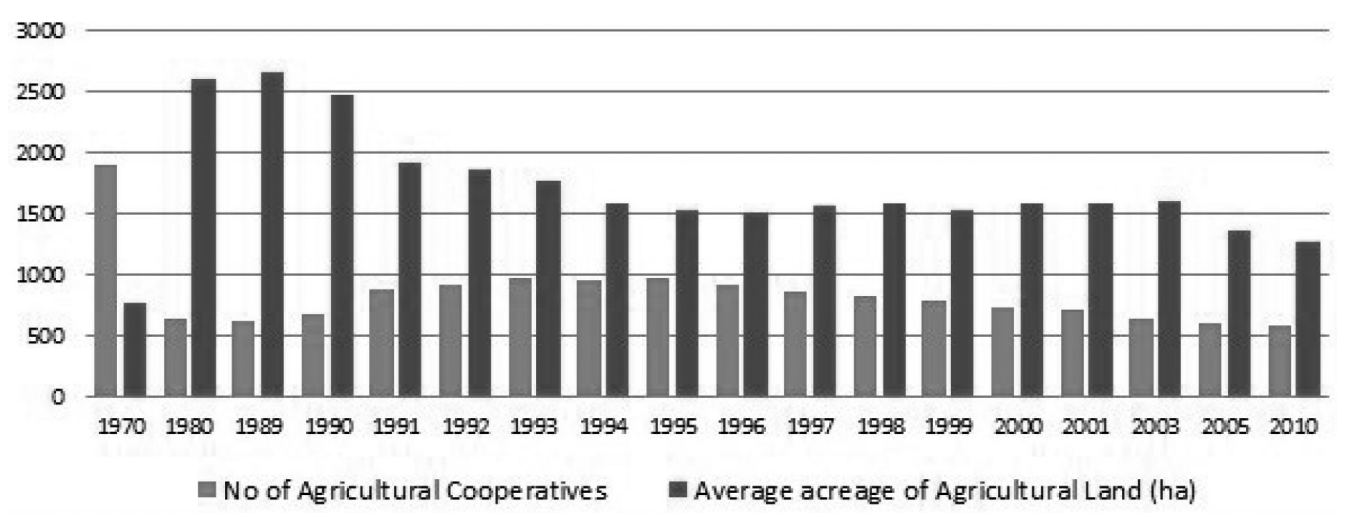

Figure 3: Development of agricultural cooperatives

Source: Green Report, MARD SR, 1996 - 2010; Structural Census of Farms 2010;

Statistical Yearbook 1970 - 2010; processing: SUA in Nitra, Department of Law

According the Figure 3, the average area of agricultural land has declined over the period approximately the same as declined the number of agricultural cooperatives in Slovakia. After 1994 (Figure 4), the share of trading companies farming on agricultural land started to increase and in 2010 it slightly exceeded the share of agricultural cooperatives.

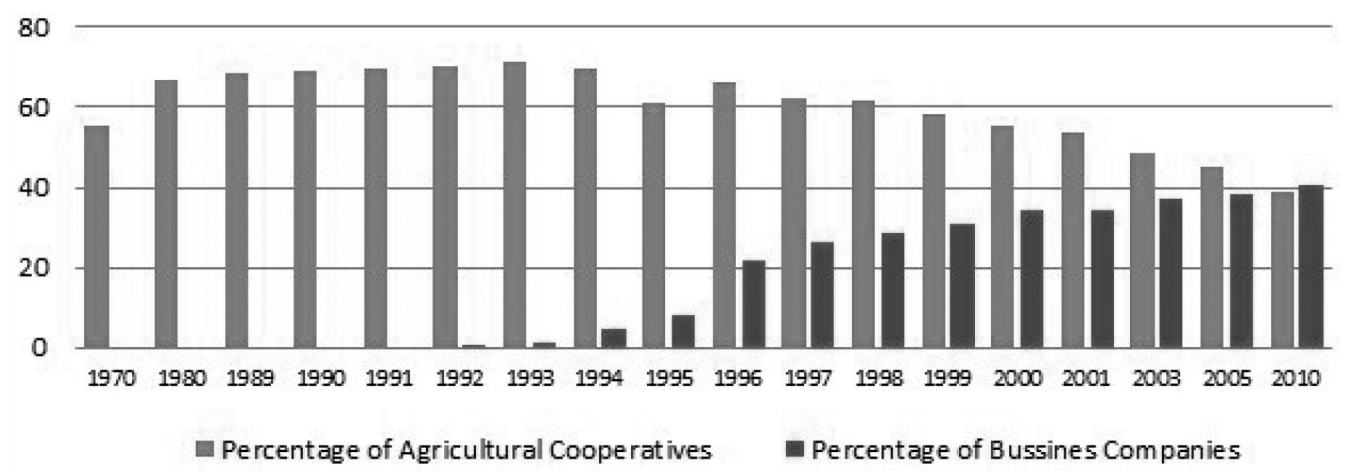

Figure 4: Percentage of cooperatives on land

Source: Green Report, MARD SR, 1993 - 2018; Structural Census of Farms 2010; processing: SUA in Nitra, Department of Law

The current legal regulation of the cooperative is characterised by openness. New members can join the cooperative and current members can leave without having to change the basic document - cooperative statutes and Business Register entries. The openness of the cooperative is governed by the legal regulation of the capital, which is the sum of all member deposits, but only a part of the so-called registered capital is recorded in the Business Register, which must be at least EUR 1,250. A cooperative must have a minimum membership base both at its establishment and throughout its existence representing by either five natural persons or two legal entities. Establishing a cooperative is easier and is not as formalized as establishing a trading company. A cooperative as a legal entity arises on the date of its entry in the Business Register provided that half of the registered capital is paid. The legal regulation of the cooperative establishes the cooperative as a share cooperative, where the member's share expresses the participation rate of a member in the cooperative, the amount of which is determined according to the ratio of the member's deposit to the registered capital, unless the statutes of the cooperative regulate its amount otherwise. A member of a cooperative may be a natural or legal person. The formation of membership, its duration and its extinction are governed by the voluntary principle. Membership may be modified in the statutes as a membership with employment relation- 
ship. The Commercial Code allows applying on cooperative the general provisions on trading companies appropriately if there is no special regulation for the cooperative.

By enshrining the legal form of the cooperative, the current legal regulation extends the range of business entities and offers to those interested in business a wider choice of forms of legal entities. The advantage of a cooperative form of business is highlighted by its flexibility. Furthermore, it is the anonymity of members not enrolled in the business register. The cooperative conducts only a non-public list of its members. In comparison with a similar regulation of a business company, the regulation of a cooperative is simpler and more liberal, given the dozens of dispositive provisions concerning the statutes of the cooperative. The statutes of the cooperative, as the basic document approved by the members of the cooperative during its establishment, deal with the fundamental issues of the internal organization of the cooperative, the mutual relations between the cooperative and its members, the mutual rights and obligations of the members towards the cooperative, the legal status of the cooperative towards third parties.

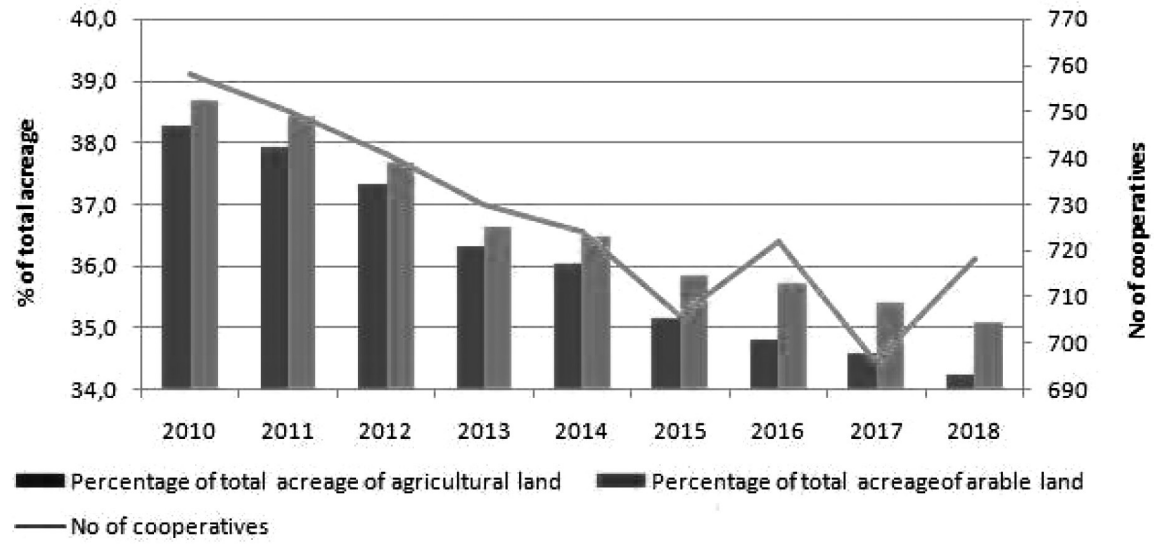

Figure 5: Development of cooperative form of business in Slovakia in 2010 - 2018 Source: The selection from the report OSEV 3-01, legal form 205 (cooperative)

Figure 5 illustrates the current state of development of agricultural cooperatives as well as the percentage of agricultural and, in particular, arable land for the period 2010 - 2018. In each of the years under review, there was a slight decrease in the number of cooperatives.

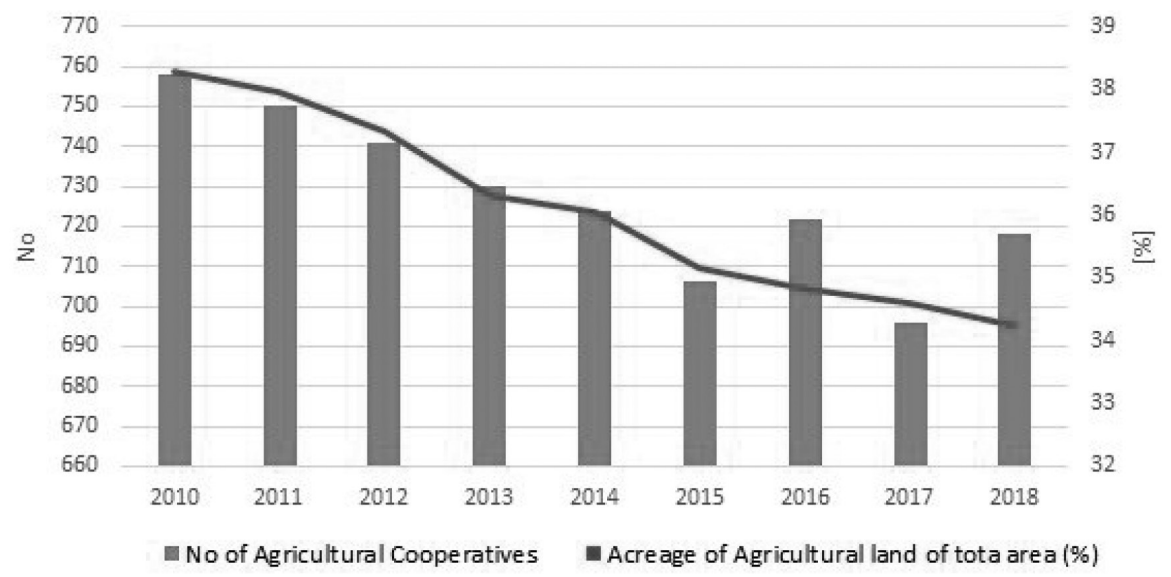

Figure 6: Percentage of cooperatives on agricultural land

Source: Research Institute of Agricultural and Food Economics - based on a selection made from the report OSEV 3-01, legal form 205 (cooperative) 
The decline in the number of cooperatives between 2010 and 2018 is also reflected in a decline of the share of the agricultural land on which they farm (Figure 6). In 2018, agricultural cooperatives farmed at 657,350 hectares representing $34.25 \%$ of total agricultural land in Slovakia.

\section{CONCLUSION}

Based on the analysis of the development of the cooperative legislation, it can be stated that the cooperative as a special business entity has its place in the structure of business entities even under current market conditions. Unlike trading companies, a cooperative as a legal entity was established spontaneously during the history and in several countries almost simultaneously to deal with the economic situation of its members by mutual help and economic self-help of members. In the conditions of the Czechoslovak Republic, especially since 1949, the gradual acceptance of rigorous regulations to the cooperative as a legal entity operating mainly in the agricultural sector has weakened the core ideas of cooperative societies and a directive regulation has started to prevail. The current legislation has united all types of cooperatives. The regulation is uniform, regardless the cooperative's subject of activity, and represents therefore an appropriate form for carrying out business activities in any area, including agriculture.

\section{REFERENCES}

[1] BANDLEROVÁ, A.: Podnikanie formou družstva na Slovensku. In: Zborník vedeckých prác Medzinárodné vedecké dni: Ekonomické a manažérske aspekty trvalo udržatelného rozvoja pol'nohospodárstva, 2001, s. 263-268 ISBN 80-7137-867-4

[2] BANDLEROVÁ, A. - LAZÍKOVÁ, J.: Some reasons that influence agrarian Land market development - Case of Slovakia. In: Development of Land Markets and Related Institutions in Countries of Central and Eastern Europe, Regional Workshop FAO, Nitra: SPU, 2005 ISBN 80-8069-515-6 3

[3] ČINTALA, P. 2007. O Európskom družstve. Žilina: PORADCA, 2007, no.11, pp. 52 ISSN 1335-1583

[4] DEMO, M. a kol. 2001: Dejiny pol'nohospodárstva na Slovensku. Nitra: SPU, 2001. 662 s. ISBN 80-7137-894-1

[5] GÁBRIŠ, T. 2012. Právo a dejiny. Právnohistorická propedeutika. Kraków: Spolok Slovákov v Pol'sku, 2012. 255 ps. ISBN 978-83-7490-490-2

[6] LAZÍKOVÁ, J.- BANDLEROVÁ A. 2007. Družstvo ako forma podnikania v polnohospodárstve $v$ podmienkach Slovenska. In: Podnikanie na pol'nohospodárskej pôde vo väzbe na rozvoj vidieka, SPU: Nitra, 2007 s. 127 - 141 ISBN 978-80-8069-872-0

[7] Ministry of Agriculture and Rural Development. 2018. Report on agriculture and food industry. Green report. Bratislava: Ministry of Agriculture and Rural Development, 2018

[8] SUCHOŽA, J. a kola kol. 2003 Obchodní zákonník a súvisiace predpisy. Komentár. Bratislava Eurounion, 2003.1017s. ISBN 80-88984-51-3

[9] ŠKRINIAROVÁ, K.-BANDLEROVÁ, A.-ILKOVÁ, Z. 2012. Nezrovnalosti v počtoch pol’nohospodárskych družstiev na Slovensku. In Ekonomika pol'nohospodárstva č. 42012. s.35-47 ISSN 1335-6186

[10] ŠTEFANOVIČ, M..1982. Právne vzt’ahy JRD. Bratislava: Príroda 1982. 259s.

[11] ŠÚBERTOVÁ, E.2004. Družstevníctvo v procese globalizácie. Bratislava: KARTPRINT 2004. s.35 ISBN80-88870-34-8 